\title{
SOCIO-LINGUISTIC ANALYSIS OF THE CHARTER OF CITIZENS' RIGHTS AND OBLIGATIONS IN HEALTH SERVICES
}

\author{
José Granero-Molina1, Cayetano Fernández-Sola², Gabriel Aguilera-Manrique ${ }^{3}$,Leonel São-Romão-Preto ${ }^{4}$ \\ Inmaculada Carmen Lara-Palomo ${ }^{5}$, Adelaida M. Castro-Sánchez ${ }^{6}$
}

\footnotetext{
${ }^{1}$ Ph.D. RN. Lecturer. Nursing, Physical Therapy and Medicine Department. University of Almería. Spain. E-mail:jgranero@ ual.es

${ }^{2}$ Ph.D. RN. Lecturer. Nursing Physical Therapy and Medicine Department. University of Almería. Spain. E-mail:cfernan@ual.es

${ }^{3}$ Ph.D. RN. Lecturer. Nursing Physical Therapy and Medicine Department. University of Almería. Spain. E-mail:gaguiler@ ual.es

${ }^{4}$ Ph.D. RN. Lecturer. Nursing Department. Escola Superior de Saúde. Instituto Politécnico de Bragança. Portugal. E-mail: leonelpreto@ipb.pt

${ }^{5}$ Research Fellow. PT. Nursing Physical Therapy and Medicine Department. University of Almería.Spain.E-mail:ilp813@ual.es

${ }^{6}$ Ph.D. RN. PT. Lecturer. Nursing Physical Therapy and Medicine Department. University of Almería, Spain. E-mail: adelaid@ ual.es
}

ABSTRACT: The aim of this study is to carry out a socio-linguistic analysis of the dissemination of the Charter of Citizens' Rights and Obligations in Public Health Services. We designed a qualitative investigation using observation and content analysis. A deductive analysis technique was followed, based on the "SPEAKING" model categories. The data analysis suggests a clear framework of rights and obligations has been established, but is not very familiar to patients and relatives. We can conclude that despite the widespread dissemination and publicity of the Citizens' Charter of Rights and Obligations, we still need the involvement of professionals. Nurses can develop a fundamental role in this process.

DESCRIPTORS: Patient rights. Health communication. Qualitative analysis. Ethics institutional.

\section{ANÁLISE SOCIOLINGUÍSTICA DA CARTA DOS DIREITOS E DEVERES DOS CIDADÃOS NOS SERVIÇOS DE SAÚDE}

RESUMO: O objetivo deste estudo foi desenvolver uma análise sociolinguística da difusão da Carta dos Direitos e Deveres dos Cidadãos nos Serviços de Saúde Pública. Desenhamos uma investigação qualitativa seguida de uma estratégia analítico-dedutiva, com base nas categorias do modelo "SPEAKING". A análise dos dados sugere que um quadro claro de direitos e obrigações tenha sido estabelecida, mas não é muito familiar para pacientes e familiares. Concluímos que, apesar da ampla difusão e publicidade da Carta dos Direitos e Deveres dos Cidadãos, ainda precisamos do envolvimento dos profissionais. Os enfermeiros podem desenvolver um papel fundamental neste processo.

DESCRITORES: Direitos do paciente. Comunicação em saúde. Análise qualitativa. Ética institucional

\section{ANÁLISIS SOCIO-LINGÜÍSTICO DE LA CARTA DE DERECHOS Y OBLIGACIONES DE LOS CIUDADANOS EN LOS SERVICIOS DE SALUD}

RESUMEN: El objetivo de este estudio es desarrollar un análisis socio-lingüístico de la difusión de la Carta de derechos y Obligaciones de los Ciudadanos en los Servicios Públicos de Salud. Diseñamos una investigación cualitativa mediante análisis de contenido y observación. Se sigue una estrategia analítica deductiva con base en las categorías del modelo "SPEAKING". El análisis de los datos sugiere el establecimiento de un claro marco de derechos y obligaciones, pero que no se ejerce habitualmente por los pacientes y familiares. Concluimos que, pese a la amplia difusión de la Carta de Derechos y Obligaciones de los ciudadanos, sigue siendo necesaria la implicación de los profesionales. Las enfermeras pueden desempeñar un papel fundamental en este proceso.

DESCRIPTORES: Derechos del paciente. Comunicación en salud. Análisis cualitativo. Ética institucional. 


\section{INTRODUCTION}

The communication between citizens and institutions shows the effort and improvement made by public health administrations in order to notify citizens of their rights and obligations as users of the healthcare system. The European Charter of Patients' Rights ${ }^{1}$ obliges the Spanish health system to make patients aware of their rights and obligations which are regulated by the General Health Act, and more specifically by the 41/2001 Basic Law on the autonomy of the patient and the rights and obligations with regard to clinical information and documentation. ${ }^{2}$ Andalusia is a region of Spain, it is provided with a Public Health System which offers global health care to citizens, regulated by the Andalusian Health Act. This Act includes the rights and obligations of users of the Andalusian Public Health System, which are developed in Chapter I (Rights of Citizens), Chapter II (Obligations of citizens concerning Health Services), and Chapter III (Warranties and Obligations of information from health administrations and centres). This act requires that there is a 'Charter or Guide' compiling all the users' rights and obligations. In the context of increasing attention to social and cultural dimensions of language, there has been growing interest in the potential of combining linguistic analysis with ethnography, in order to probe the interrelationship between language and social life in more depth. ${ }^{3}$ The aim of this study is to carry out a socio-linguistic analysis of the dissemination of the Charter of Citizens Rights and Obligations in the Public Health Services of Andalusia (CCROPHSA). ${ }^{4}$

\section{Background}

Health care as a right, peoples' health is an important factor in measuring social and economic well-being. Furthermore, users around the world are increasingly being asked to take more responsibility for their own health care as this delivery evolves. ${ }^{5}$ As the patients' rights increase, there is an obvious need to balance them with those of health caregivers (physicians, nurses, etc.) within a process covering professional ethics, codes of conduct and the harmonisation of general legal principles with national and international legislations. ${ }^{6}$ From the Amsterdam Declaration on the Promotion of Patients' Rights in conjunction with the World Health Organization, ${ }^{7}$ countries have progressively enacted laws regarding patients' rights, charters or their equivalent, featuring among them Spain and Andalusia, a region with its own competences in healthcare policies.

Some reasons for the problematic nature of institutional communication are incongruent frames of reference about what information ought to be shared, sociolinguistic differences and social distance between practitioners and patients. This right to information includes knowing the healthcare services, its quality standards and access requirements. Although these documents establish responsibilities with varying degrees of specificity, legal status and enforceability; health centres are obliged to have a Patients' Charter and to ensure its implementation. ${ }^{8}$

The study of language is a multidisciplinary field to wich not only linguistics but also other disciplines are indispensable. It is important to explore those factors having an influence on the context where this communicative act among patients, professionals and institutions takes place. It was the socio-linguist Dell Hymes who studied the socio-cultural adaptation of a statement to a given context ${ }^{9}$ understanding by communicative competence one including a grammar competence as well as a socio-linguistic context (knowledge of the socio-cultural context where the language is used). He supports the idea that each communicative act is organised according to eight components, developing a model of documentary analysis and the speech acts, and allowing the study of language use within the community where communication happens. Its use in the CCROPHSA ${ }^{4}$ analysis would allow the study of the clinical context and the circumstances surrounding the communicative situation. Several studies have already used these analysis models in diverse situations, and from the approach of the Health Sciences, in the documentary analysis of the informed consent ${ }^{10}$ and the study of the rights and obligations of patients and nurses. ${ }^{11}$

\section{MATERIAL AND METHODS}

Content analysis offers researchers a flexible, pragmatic method for developing and extending knowledge of the human experience of health and illness. ${ }^{12}$ Content analysis is a research approach to improve researcher understanding of particular phenomena or inform of practical strategies. ${ }^{13-14}$ The study was conducted between December 2011 and May 2012, employing a qualitative content analysis methodology. ${ }^{15-16}$ Initial contact was made with the subject at the pre-analysis stage. An initial question was posed at the design stage: could the dissemination of the CCROPHSA be 
improved? The analysis unit was then selected in line with the text (CCROPHSA), alongside observational notes developed by two observers in five hospital dependencies. Going into the field implies more than access to data, we studied the information provided to patients, your interest and the questions to health professionals. ${ }^{17}$ Conducted anonymously and individually by two nursing researchers, through an observation lasting 10 days in five areas of the Andalusia Public Healthcare Services (APHS): admission room, hospitalization room, medical consulting room, emergency room and nursing consulting room, the observations focused on the communication between patient, family and the care providers (nurse, physician).

For the analysis, a deductive categorization ${ }^{18}$ was carried out following the SPEAKING model, together with the assignment of text extracts and observations to said categories. The SPEAKING model, ${ }^{19}$ described by Dell Hymes, allows for the analysis of the communicative act in context, and is focused on:

$S$ (Settings and scene): framework where the communicative act takes place, type of communication and linguistic barriers. Communicative act which involves health professionals, citizens and institutions, an act of institutional communication aimed at informing all users of the APHS of their rights and obligations. The role of the institutions is to provide users with information about their rights and obligations, an effort made in order to update the healthcare services from a paternalistic health system to a modern organisation where the patient is considered the "core of the health system".

P (Participants): who they are and which roles are played by each one taking part in the communicative act. Institution: responsible for sending messages to a target population (patients and relatives) by way of several resources, which in our case, would be the display of information panels along with the 'User's Guide' including the CCROPHSA. Users: they are the message recipients acting in accordance with their rights and obligations and reporting their experiences through complaint forms or satisfaction questionnaires. Professionals: they are the intermediaries and they should have enough resources to inform, re-direct and sort out inquiries made by users.

E (End): aims, objectives and results. This answers the question of 'what for' and concerns the objectives and goals to communicative action.

A (Act sequence): content and style of the used expressions.
$\mathrm{K}$ (Key): answers the question of how the communicative act is executed.

I (Instrumentalities): this refers to the linguistic resources that have been used as well as to the connection among words, phrases and paragraphs.

$\mathrm{N}$ (Norms): this answers the question of 'which standards', and includes general patterns that allow us to interpret what is said or written.

$\mathrm{G}$ (Genre): this answers the question of 'which type of discourse' and refers to analysing the symmetry of participants, and the formats used in written communications.

The analysis carrying out three next steps:

1. An individual analysis: developed by three researchers searching significant parts of the datafor each of the eight categories of the SPEAKING model.

2. A group analysis: carried out by three researchers studying the lexis, syntax and semantics together with individual observations. Consensus techniques were used to assign text extracts CCROPHSA and observations to the different SPEAKING model categories. The assignment of quotes to the model categories was carried out in line with a minimum agreement percentage of $66 \%$ between researchers.

3. Interpretation of results, combining manifest content and the latent content.

\section{Ethical issues}

The study was conducted according to the necessary ethical standards, was approved by the Nursing, Physiotherapy and Medicine Department of the University of Almeria, Spain, with the protocol number 07/2011.

\section{RESULTS}

\section{Situation (setting and scene)}

Observers' notes inform of the CCROPHSA distribution in different healthcare institution centres and facilities: the Charter displayed in information panels around health centres is seen in waiting rooms, transit areas, physicians' offices, rooms and also in a User's Guide given to the patient when admitted (O1).

On top of this, there are many linguistic barriers to overcome: It is only a piece of written information as the text does not come with a verbal explanation and despite understanding 
the language, it will always depend on the users' interest and willingness to read it. This matter has been shown through observing different hospital areas where users hardly ever require an explanation in this respect $(\mathrm{O} 2)$. The format does not include any graphic illustration or images breaking the monotony of the text.

A large percentage of the APHS users are foreigners that are not familiar with the Spanish language (high rate of immigrants from subSaharan Africa and the Maghreb along with tourists from England and Germany). The 'Charter' has been translated into six languages and is displayed in every centre according to the most spoken languages. Institutions are also provided with a translation service and written manuals on symptoms and most common questions, but they are rarely required for any explanation related to the CCROPHSA $(\mathrm{O} 2)$.

Another important barrier emerges with the clinical status of the patient (unconscious, in intensive care, immobilised, etc.) where in such cases, a relative is informed.

\section{Participants (status and role)}

The lack of attention users pay to the CCROPHSA stands out; they hardly stop to read it thoroughly and the professionals do not encourage them to do so either: the professional only intervenes when users want to execute any of their rights therein $(\mathrm{O} 2)$.

\section{End}

The aim of the communicative act is conveying information to citizens about their main rights and obligations as users of the public healthcare services.Your rights as a user of the healthcare system [...]. Your obligations as a user of the healthcare system (CCROPHSA).

\section{Act sequence}

Socio-linguistics of treatment: the document uses standardized, polite expressions, respectful but cold and distant, directly addressing the user: to have access to your medical records, using the established procedures (CCROPHSA). Fragmented discourse: the document details extracts from a larger text, mixing patients' rights and obligations applicable to different and specific situations. Sequence of communication: the patient uses the health service; the institution informs them of their rights and obligations; the patient processes said information in relation to their own experience and resolves any doubts by consulting appropriate professional persons (O1). They advise the institution of the fulfilment of said processes by means of written documents such as suggestions forms and complaints or letters to the management team.

\section{Key}

The tone of the text is highly formal, although its language generally excludes periphrasis and legal terminologies and technical medical terms are scarce. It deals with a powerful text, given that its content gives the patient the power to: decide, choose, and demand compliance with deadlines and dignity during treatment: to have a second medical opinion on your process, in the terms established (CCROPHSA). It is a document which evens out the doctor-patient power relation by the inclusion of a third party - the health institution which looks after the interests of the users of the healthcare services.

\section{Instrumentalities}

The institutional communication document employs lexical resources adapted to be understandable for patients, expressed using infinitives and impersonal sentences: to receive..., to know..., to have access..., to choose... (CCROPHSA). Technical terms do not appear, although much medical science vocabulary, some of which cannot be considered 'everyday' language, is used: new genetics technology ... surgical procedures and tests that involve risks (CCROPHSA). Given that the text has a legal origin, it utilizes phraseology typical to such texts, but does not use metaphorical or literary terms; nor does it use euphemisms, voicing challenging circumstances without hiding their nature as a critical situation: risk for public health, incapacity and urgent intervention in cases of risk of irreversible injury or danger of life (CCROPHSA). The text is direct; the institution addresses the users of the health care system in the third person singular, using 'usted' (formal 'you' in Spanish). A dialogue-style layout (question-response) is not employed. Syntactic resources: there is one single title for the rights and another for the obligations.

\section{Norms}

Interaction norms: the patient receives the information on being admitted (O2). If this information has already been prepared, he/she can read it and 
request any clarifications before being subjected to any treatments or procedures (in the case of emergencies, the information will be given after the patient's recovery). The professional takes action when the user exercises any of his/her rights, or serves to remind the patient of his/her obligations (O1). Their obligation is to give a reply to the patient with regards to their situation, to advise them on exercising their rights and to explain terms and information in a clear and comprehensive manner.

Interpretation norms: in many cases, rights are included in the margins with terms granting the health institution exemption from taking immediate action: provided that clinical circumstances so permit... in the terms established... to receive healthcare in an acceptable time, depending on the process... (CCROPHSA). Vital elements such as the waiting time for a surgical procedure or the right to a free choice of professional are not fully discussed nor clarified.

\section{Genre of the communication act}

The text lacks presentation, an introduction, a summary and conclusions. It is organised in a sequence of informative text, with the typical asymmetrical relationships between the professional-patient and the institution-user.

\section{DISCUSSION}

The practice of health professionals in the hospital environment has been losing its human characteristics. ${ }^{20}$ In contrast with the former, paternalistic view of medical support, the aim of public health institutions is to focus on the patient, attending to his/her needs and health expectations. The health care given to a patient implies scientific and socio-cultural questions and a wide variety of experts and methodologies have been used to solve these problems. In a health system dominated by technology, the vulnerability of the hospitalised patient demands the preservation of his/her dignity, privacy and confidentiality. ${ }^{21}$

Linguistic matters, language and documentation are vital in the communication of symptoms and requirements, preventing the increased risk and allowing the patient to exercise his/her rights. ${ }^{22}$ Although the institutional intercourse is neutral with regards to race, cultural language and religion, it is difficult to avoid its influence in a society with a strong immigration background, where over 90 languages and dialects converge. The majority of the African emigrant population to Europe pass through Andalusia and it is also a popular region for European immigrants (mainly elderly people), where the public health institutions attend to patients of numerous nationalities. Care has to be taken with regards to language skills so that the rights of the patients are not seen as compromised, nor that they result in adverse effects for their health. ${ }^{23}$ However, this is not guaranteed by merely translating the Patient's Charter into another language, but by its consequent circulation and application. Communication and interaction in accident and emergency environments is even more complicated due to the serious state of the patient, the stress put on the professional and the anxiety of the relatives; here, the CCROPHSA is generally overlooked.

The text does not come with a verbal explanation. However, the health professional is increasingly being seen as someone who helps the person access, validate and process information so as to empower the individual in future rights. Despite the importance attached to issues related to rights and responsibilities, patients' perceptions of the Patient's Charter were mostly absent or ambivalent. If users do not have the necessary and sufficient information, they do no not feel capable of exercising and/or fighting for their rights, ${ }^{5}$ which hinders the full exercise of their autonomy. ${ }^{24}$ Without the involvement of professionals, institutional communication would be "nothing" - a matter to take into consideration in the ethical training of the professionals, above all the nurses, ${ }^{25}$ who should commit themselves to more than just individual care, but also to defending the patients' rights. ${ }^{5-26}$

The aim of the communicative act is to improve the user's information, because many patients support greater involvement in service delivery, but they want professionals to recognise that this needs to be optional and varies according to the context. ${ }^{27}$ On being admitted to hospital, the patient not only has to readjust to the regulations in place, but also to exercising his/her rights. For this reason, the Patient's Charter encourages them to express their opinions, make decisions and take responsibility for their own illness, providing them with the necessary information. ${ }^{28}$ The language of the analysed document is clear and comprehensive, with few expressions needing additional explanations; the use of different linguistic registers such as medical terminology and everyday language is not noticeable. Although the Patient's Charter is an extract from a Basic 
Law which provides the patient with information without losing its original meaning, some gaps in information have been identified which could be improved by separating and displaying the rights/ responsibilities in areas where they would be more relevant and of use, accompanied by more visual information. For example, the patients' admission area (to choose a specialist for consultations ...), hospitalization room (to know the name and function of the caregivers).

The patients', relatives' and professionals' familiarity with the Patient's Charter is vital for its success, but knowledge of it is scarce, especially regarding choice of hospital, specialist physician or the right to receive a second opinion about a diagnosis or treatment. The Patient's Charter is sometimes seen as just another document, without effect and of little use, specifically lacking in access to services, improving information and methods to observe the efficiency of results. ${ }^{29}$ Similar to other Mediterranean countries, the idea of patient rights is new in Spain, ${ }^{30}$ as traditionally patients complied with the doctor's orders, asked few questions and if they wanted to complain, they did so verbally, leaving little written documentation and records. The relation of users' experiences is key to fulfilling the institutional communication process and allowing for feedback for evaluation. Satisfactory institutional communication must include a respect of rights; for this reason, Patients' Charters are promoted by governments themselves, but also incorporate a section with the obligations of the patient. These basic documents analyse health policies and show the most common rights as access to information and free choice of health centre and the least represented as dignity and responsibility. ${ }^{31}$

The shortage of personnel, ${ }^{32}$ an excess of patients or lack of technology can sometimes mean that the Patient's Charter is not fully observed, ${ }^{33}$ even though the document is fundamental to creating safer care environments. ${ }^{34}$ Furthermore, other cases have described it as an obstacle and a cause of problems for professionals. ${ }^{35}$ The Patient's Charter usually generates expectations regarding medical attention which cannot always be met in such critical situations, with a lack of trust and suspicions among the members of the multidisciplinary team themselves sometimes being evident. ${ }^{36}$

Some users experience hospitalisation as a completely new situation - unpredictable, impersonal and stressful. ${ }^{37}$ They require information, and although they may not always wish to ac- tively participate in the process, it is a right which should be protected, most of all by the nurses, ${ }^{38}$ as 'defenders' of the patient. Some studies of user complaints have already shown the information of the CCROPHSA to be hardly known and lacking the involvement of professionals in its development. ${ }^{39}$ This justifies the need for professionals who support the Charter dissemination. As such, their actions as a mediators in the observation and development of the Patient's Charter will give meaning and value to this institutional communication. ${ }^{5,40}$ The nurse has to react to the cultural change, relying on the development of skills to strengthen his/her role in these processes. ${ }^{41}$ This implies: encouraging the active participation of the other professionals in the dissemination of the CCROPHSA, prompting patients and families to read and understand it, channelling the demand for information, adapting the language to the users' cognitive and cultural capacities, resolving doubts and ensuring the rights are complied with. Similarly, the users should be informed of the possibility to make complaints or suggestions, remembering the need to fulfil their obligations with regard to healthcare institution regulations and the use of resources.

Nurses should work effectively to disseminate the patients'rights, so that benefits are guaranteed and their condition as citizens is respected. ${ }^{42}$ Changing a hospital culture is not easy, but evidence is accumulating that this process needs to be started ${ }^{43}$ Content analysis is similar to other qualitative methods in that it is an interpretive process and cannot be generalised to other situations/speech acts. The conclusions of this study can only be applied to the context in which it was carried out, and could be different in other countries.

\section{CONCLUSIONS AND IMPLICATIONS}

In a communicative act analysed in a complex clinical environment, three channels of communication have been established:

1. Institution-user: communication from the institution to the user via the 'Patients' Charter' could be subject to language barriers, para-linguistic barriers and non linguistic barriers.

2. User-professional: respect for the majority of the patient's rights has already been incorporated into daily (routine) practice (informed consent, discharge report, etc.). In other cases, the user can communicate her/her demand to exercise his/her 
rights to a professional who either addresses them or advises them on any regulations.

3. Professional-institution: it is the weakest area in terms of communication, despite being the Charter issued by the institution, a higher level of awareness is required from the professionals as they are who have to attend to them or help them.

The framework of rights and responsibilities of patients in Andalusia is well-established, although professionals', patients' and relatives' knowledge could be rather scarce. The analysis of communicative acts through socio-linguistic technique could be useful in detecting strengths and weaknesses of the institutions. Our results suggest that merely the dissemination of the CCROPHSA is not enough to make users aware of it and put it into practice. The disclosure of the CCROPHSA could be improved by using shorter messages; adapted to specific stages of medical assistance, by more visual means and, above all, involvement and dedication from the professionals. The user's confidence in the public health system is supported by institutional and personal information, but both need a 'face'; this is the challenge for the nurse.

Future investigations would benefit from the participation of patients, families and researchers from other disciplines, as well as from triangulation with other methodologies.

\section{REFERENCES}

1. Active Citizenship Network (ACN). European Charter of Patients' Rights. Basic Document. Roma (IT): ACN; 2002.

2. Spain. Ley 41/2002, de 14 de noviembre, básica reguladora de la autonomía del paciente y de derechos y obligaciones en materia de información y documentación clínica. Boletín Oficial del Estado, 15 Nov 2002.

3. Tusting K, Maybin J. Linguistic ethnography and interdisciplinarity: opening the discussion. J Socioling. 2007 Nov; 11(5):575-83.

4. Gobierno de Andalucía, Consejería de Salud. Rights and obligations of citizens in the public health services of Andalucía [online]. 1998 [cited 2011 Nov15]. Available from: http://www. juntadeandalucia.es/agenciadecalidadsanitaria/ observatorioseguridadpaciente/gestor/sites/Portal Observatorio/es/galerias/descargas/Inglxs.pdf

5. Santos ECB; Teixeira CRS; Zanetti ML, Santos MA. Exercising the rights of health care users with Diabetes Mellitus: co-responsibilities among public power, health professionals, and users. Texto Contexto Enferm. 2011 Jul-Sep; 20(3):461-70.
6. Palm B, Baeten R. The quality and safety paradox in the patients right directive. Eur J Public Health. 2011 Jun; 21(3):272-4.

7. World Health Organization (WHO). European consultation on the rights o patients. A declaration on the promotion of patients' rights in Europe [online]. Amsterdam (NL): WHO; 1994 [cited 2012 Jun 20]. Available from: http://www.who.int/ genomics/public/eu_declaration1994.pdf

8. Schmidt H. Patients' charters and health responsibilities. Brit Med J. 2007 Dec; 335(7631):1187-9.

9. Hymes, D. Ethnography of communication. In: Garvin P, Lastra Y, editors. Studies anthology of sociolinguistics and ethnolinguistic. México (MX): Universidad Autónoma de México; 1984. p. 48-89.

10. Granero-Molina J, Fernández-Sola C, AguileraManrique G. Applying a sociolinguistic model to th eanalysis of informed consent documents. Nurs Ethics. 2009 Nov; 16(6):797-812.

11. Oduor B, Maina P, Atieno E. Face attack and patients' response strategies in a Kenyan hospital. J Socioling. 2010 Sep; 14(4):501-23.

12. Gbrich C. Qualitative data analysis: an introduction. London (UK): Sage Publications; 2007.

13. Krippendorf K. Content analysis: an introductory to its methodology. California (US): Sage Publications; 2004.

14. Graneheim UH, Lundman B. Qualitative content analysis in nursing research: concepts, procedures and measures to achieve trustworthiness. Nurs Educ Today. 2004 Feb; 24(2):105-12.

15. Hsiu-Fang H, Shannon SE. Three approaches to qualitative content analysis. Qual Health Res. 2005 Nov; 15(9):1277-88.

16. Guix J. El análisis de contenidos: ¿qué nos están diciendo? Rev Calid Asist. 2008 Jan; 23(1):26-30.

17. Soto-Lesmes VI, Durán MD. Field work: key to qualitative research. Aquichán. 2010 Dec; 10(3):25366.

18. Humble AM. Technique triangulation for validation in directed content analysis. IJQM. 2009 Jul-Sep; 8(3):34-51.

19. Hymes D. Models of the interaction of language and social settings. J Soc Issues. $1967 \mathrm{Apr} ; 23(2): 8-28$.

20. Stein DS, Lerch V, Lunardi WD. Hospital humanization as an expression of ethics. Rev Latino-am Enfermagem. 2006 Jan-Feb; 14(1):132-5.

21. Matiti MT, Gillian Trorey GM. Patient's expectation of the maintenance of their dignity. J Clin Nurs. 2008 Oct; 17(20):2709-17.

22. Nailon R. The assessment and documentation of language and communication needs in healthcare system: current practices and future directions for coordinating safe, patient-centred care. Nurs Outlook. 2007 Nov; 55(6):311-7. 
23. Whitman MV, Davis JA. Registered nurses perceptions of cultural linguistic hospital resources. Nurs Outlook. 2009 Jan-Feb; 57(1):35-41.

24. Barbosa EC, De Souza CR, Zaneti ML, Dos Santos MA, Alves MC. Health services users with Diabetes Mellitus: from knowledge to the use of healthcare rights. Rev Latino-Am Enfermagem. 2011 Mar-Apr; 19(2):285-92.

25. Deshpande SP, Jakobs J, Prasad R. Factors impacting ethical behaviour in hospitals. J Bus Ethics. 2006 Dec; 69(2):207-16.

26. Chan EA, Jones A, FungS, Wu SC. Nurses' perception of time availability in patient communication in Hong Kong. J Clin Nurs. 2012 Apr; 21(7-8):1168-77.

27. Thompson A. The meaning of patient involvement and participation in health care consultations: A taxonomy. Soc Sci Med. 2007 Mar; 64(6):1297-310.

28. Ryan J, Syisko J. The contingency of patient preferences for involvement in health decision making. Health Care Manage Rev. 2007 Jan-Mar; 32(1):30-6.

29. Flood C, May K. A patient charter of rights: how to avoid a toothless tiger and achieve system improvement. CMAJ. 2012 Oct; 184(14):1583-7.

30. Merakou K, Dalla-Vorgia P, Garanis-Papadatos T, Kourea-Kremastinou J. Satisfying patients' rights: a hospital patient survey. Nurs Ethics. 2001 Nov; 8(6):499-509.

31. Rider ME, Makela C. A comparative analysis of patient's rights an international perspective. Int J Stud Consum. 2003 Sep; 27(4):302-15.

32. Büken NÖ, Büken E. Emerging health sector problems affecting patient rights in Turkey. Nurs Ethics. 2004 Nov; 11(6):610-24.

33. Migone M, Nicholas FM, Lennon R. Are we following the European charter? Children, parents and staff perceptions. Child Care Health Dev. 2008
Jul; 34(4):409-17.

34. Joolaee S, Tschudin V, Nikbakht-Nasrabadi A, Parsa-Yekta Z. Factors affecting patients' rights practice: the lived experiences of Iranian nurses and physicians. Int Nurs Rev. 2008 Mar; 55(1):55-61.

35. Sbaih L. Meanings of immediate: the practical use of the Patients' Charter in the accident and emergency department. Soc Sci Med. 2002 May; 54(9):1345-55.

36. Day L. Advocacy, agency and collaboration. Am J Crit Care. 2006 Jul; 15(4):428-30.

37. Patiraki M, Karlou Ch, Balogh Z, Palese A, Tomietto M, Jarosova D, et al. Patients' and nurses' perceptions of respect and human presence through caring behaviours: A comparative study. Nurs Ethics. 2012; 19(3):369-79.

38. Chaves PL, Costa VT, Lunardi VL. Nursing in front of hospitalized patients rights. Texto Contexto Enferm. 2005 Jan-Mar; 14(1):38-43.

39. Fernández-Sola C, Granero-Molina, J. Users' claims, an instrument to evaluate nursing. Index Enferm [online]. 2004 [acess 2012 Jan 16]; 47:21-5. Available from: http://www.index-f.com/indexenfermeria/47revista/47e21-25.php

40. Vaartio H, Leino-Kilpi H. Nursing advocacy-a review of the empirical research 1990-2003. Int J Nurs Stud. 2005 Aug; 42(6):705-14.

41. Brooks F. Nursing and public participation in health: an ethnographic study of a patient council. Int J Nurs Stud. 2008 Jan; 45(1):3-13.

42. Megumi H, Scatralhe L, Fontao MM. Cancer patients' knowledge about their legal rights. Rev Esc Enferm USP. 2011 Apr; 45(2):339-45.

43. Fakhr-Movahedi A, Salsali M, Negharandeh R, Rahnavard Z. A qualitative content of nurse-patient communication in Iranian nursing. Int Nurs Rev. 2011 Jun; 58(2):171-80. 